\title{
Treatment of Wastewater from the Confectionery Industry Using Pressure Membrane Processes ${ }^{\dagger}$
}

\author{
Ewa Puszczało * and Anna Marszałek \\ Faculty of Energy and Environmental Engineering, Silesian University of Technology, Konarskiego 18, \\ 44-100 Gliwice, Poland; anna.marszalek@polsl.pl \\ * Correspondence: ewa.puszczalo@polsl.pl \\ + Presented at Innovations-Sustainability-Modernity-Openness Conference (ISMO'19), Bialystok, Poland, \\ 22-23 May 2019.
}

Published: 25 June 2019

\begin{abstract}
The aim of the research presented in this article was to present the possibilities of wastewater treatment coming from the confectionery plant using pressure membrane techniques. Nanofiltration was carried out in a pressure dead-end filtration set up (Osmonics type GH-100-400) with a cell capacity of $350 \mathrm{~cm}^{3}$ equipped with a magnetic stirrer. Four flat nanofiltration membranes were used during the tests. The efficiency of the process was estimated by determining the purified wastewater volumetric stream and based on the removal degree of pollution load. The nanofiltration membrane, thanks to which the highest cleaning results were obtained, is a flat composite membrane, with the symbol NF-270, with the polyamide film layer of the Dow Filmtec company. The degree of removal of COD after nanofiltration in this membrane was $98.7 \%$. It was found, that wastewater treated by pressure membrane techniques in the confectionery industry can be reused, for example, for irrigation of agricultural land or gardens, and for machines and equipment washing (closing water circuits). The use of NF processes enables wastewater treatment to such a degree that it can be drained to a natural receiver.
\end{abstract}

Keywords: sugar wastewater; membranes; nanofiltration

\section{Introduction}

The aim of the research presented in this article was to present the possibilities of wastewater treatment coming from the confectionery plant using pressure membrane techniques. The activity of confectionery plants requires a considerable amount of fresh water used in the production, as well as for machines and equipment washing, which generates large amounts of wastewater.

Wastewater from the food industry contains a high level of organic compounds expressed as COD and BOD. They can be up to 10 times higher compared to municipal waste. Wastewater discharging characterised by a high load of organic compounds can create a serious environmental problem. That is why, before the discharge of such wastewater to the environment, it should be properly cleaned [1-3].

In highly developed countries, closed water circuits and heat recovery systems are used. To be able to use the technological water, the applied methods of wastewater treatment must guarantee the removal of almost total organic mass and compounds that may cause interference in a given industry. For the wastewater treatment in a closed cycle, mainly physicochemical methods are used, such as chemical precipitation, sorption, membrane filtration. More expensive, more modern technology of wastewater treatment, such as nanofiltration or reverse osmosis, allows more effective purification. The advantage of these methods is that after the treatment process there are no semi-finished products of pollutant decomposition and additional chemicals in the wastewater [4-7]. 


\section{Material and Methods}

The substrates of the initial tests were aqueous solutions prepared on the basis of tap water containing dissolved food sugar (crystallised sucrose) in the amount of $5 \mathrm{~g} / \mathrm{L}$. Then, an attempt was made to purify the real wastewater from the confectionery industry, which was taken from the confectionery plant in the Silesian province. Table 1 presents the physico-chemical characteristics of the treated wastewater subjected to pressure membrane filtration.

Table 1. Physico-chemical characteristics of the treated wastewater subjected to pressure membrane filtration.

\begin{tabular}{|c|c|}
\hline Parameter & Sugar wastewater \\
\hline $\mathrm{COD}(\mathrm{mg} / \mathrm{L})$ & 8170 \\
\hline BOD (mg/L) & 2600 \\
\hline $\mathrm{N}-\mathrm{NO}^{3-}(\mathrm{mg} / \mathrm{L})$ & 49.5 \\
\hline $\mathrm{N}-\mathrm{NH}^{4+}(\mathrm{mg} / \mathrm{L})$ & 12 \\
\hline $\mathrm{P}^{-\mathrm{PO}_{4}{ }^{3-}(\mathrm{mg} / \mathrm{L})}$ & 17.4 \\
\hline $\mathrm{pH}$ & 7.00 \\
\hline
\end{tabular}

Four commercial nanofiltration membranes were used in the research. The characteristics of nanofiltration membranes are shown in Table 2.

Table 2. Characteristics of nanofiltration membranes (producer's data).

\begin{tabular}{ccccc}
\hline Symbol & DK & TS40 & NF-270 & NP010 \\
\hline Producer & GE & Trisep & Dow Filmtec & Microdyn Nadir \\
Material & $\begin{array}{c}\text { Polyamide } \\
\text { skin layer }\end{array}$ & Amide polipiperazine & Polyamide skin layer & Polyethersulfone \\
MWCO (Da) & $150-300$ & 200 & 200 & 1000 \\
pH & $2-10$ & $2-11$ & $2-10$ & $0-14$ \\
\hline
\end{tabular}

The obtained results were compared, and the choice of the best membrane was made, which then was used to purify the real wastewater from the confectionery industry.

The efficiency of the process was estimated by determining the purified wastewater volumetric stream and based on the removal degree of pollution load. During the processes, the volume of the received filtrate was measured, which allowed calculating the value of the deionised water flux $\left(\mathrm{J}_{\mathrm{w}}\right)$ and the filtrate flow $\left(J_{v}\right)$ from the general dependence: $J=V /(A \cdot t)$. Designation: $V-$ volume of permeate, $\mathrm{m}^{3}, \mathrm{~A}$-area of the membrane, $\mathrm{m}^{2}, \mathrm{t}$-time, $\mathrm{s}$.

The evaluation of the effectiveness of a treatment process was based on the change of wastewater quality indicators before and after the membrane process. Following parameters were controlled: $\mathrm{COD}, \mathrm{BOD}, \mathrm{N}-\mathrm{NO}_{3}{ }^{-}, \mathrm{N}-\mathrm{NH}_{4}{ }^{+}, \mathrm{P}-\mathrm{PO}_{4}{ }^{3-}$. Nitrate and ammonium nitrogen, as well as COD and phosphate phosphorus, were measured according to the methodology given by Merck company. The BOD was determined by the respirometric method using OXI Top WTW analysing.

Nanofiltration was carried out in a pressure dead-end filtration set up (Osmonics type GH-100400) with a cell capacity of $350 \mathrm{~mL}$ equipped with a magnetic stirrer.

\section{Results and Conclusions}

In the initial stage of the research, the transport characteristics of the applied nanofiltration membranes for deionised water were determined. The transmembrane pressures in the range of $0.5-$ 2.0 MPa were used. In Figure 1 the dependence of the volume deionised water flux $\mathrm{J}_{\mathrm{w}}$ on the transmembrane pressure during the nanofiltration process was shown. 


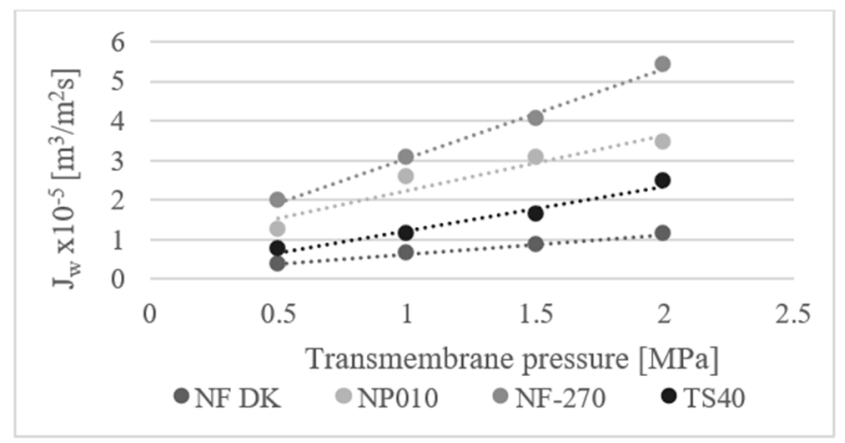

Figure 1. Dependence of the volumetric water on the transmembrane pressure for nanofiltration membranes.

The most significant volume water stream was obtained during the process on a flat composite membrane with the polymer skin layer with the symbol NF-270 from Dow Filmtec. This value is $27 \%$ higher than the volumetric water stream in the case of polysulfone nanofiltration membrane Nadir NP.010.

Then, model wastewater filtration was carried out using all tested nanofiltration membranes. The efficiency of the nanofiltration process for all membranes was adequate for deionised water filtration. Differences in the nanofiltration membranes efficiency resulted most probably from their thickness and surface properties. Volumetric permeate stream for the NF-270 membrane was at the level of $3.85 \times 10^{-5} \mathrm{~m}^{3} / \mathrm{m}^{2} \mathrm{~s}$ and was $29 \%$ lower than the volume stream of deionised water. The effectiveness of model wastewater purifying and the selection of the best nanofiltration membrane was also determined based on the COD reduction rate. Based on the above results, it can be concluded that the composite membrane NF-270 had the highest efficiency and was characterised by the highest removing organic compounds efficiency. In the next stage of the research, an attempt was made to purify real wastewater from the confectionery industry. This wastewater was subjected to initial purification in the ultrafiltration process. An ultrafiltration membrane of the HZ15 symbol from Osmonics was used for this purpose. After the initial purification, the filtrate was directed to a selected nanofiltration membrane to separate multivalent ions, bacteria and organic impurities. For this purpose, the NF-270 membrane was used. In Table 3 the results of tests for real wastewater from the confectionery industry was presented.

Table 3. Value of pollution indicators for raw, after ultrafiltration and after nanofiltration wastewater.

\begin{tabular}{cccc}
\hline Parameter & Real wastewater & Wastewater after UF & Wastewater after NF \\
\hline $\mathrm{COD}(\mathrm{mg} / \mathrm{L})$ & 8170 & 8060 & 100.1 \\
$\mathrm{BOD}(\mathrm{mg} / \mathrm{L})$ & 2600 & 1500 & 20 \\
$\mathrm{~N}^{-\mathrm{NO}^{3-}}(\mathrm{mg} / \mathrm{L})$ & 49.5 & 49.5 & 18.3 \\
$\mathrm{~N}-\mathrm{NH}^{4+}(\mathrm{mg} / \mathrm{L})$ & 12 & 12 & 7 \\
$\mathrm{P}-\mathrm{PO}_{4}^{-3}(\mathrm{mg} / \mathrm{L})$ & 17.4 & 6.2 & 0 \\
\hline
\end{tabular}

\section{Conclusions}

On the basis of the conducted tests, it can be concluded that the use of pressure membrane processes allowed for significant removal of impurities. The value of COD indicator after nanofiltration decreased by eight times in relation to the COD value of raw wastewater, as well as a high level characterised by the removal of biogenic compounds level. It can be concluded that the composite membrane with the polyamide skin layer of the NF-270 symbol from Dow Filmtec stopped the impurities contained in the industrial wastewater from sugar plants that they could be discharged to the natural receiver.

Author Contributions: E.P. conceived and designed the experiments; E.P. performed the experiments; E.P. and A.M. analysed the data and contributed reagents/materials/analysis tools; E.P. and A.M. wrote the paper. 
Acknowledgments: The work was financed from the MNiSW grant for statutory activity.

Conflicts of Interest: The authors declare no conflict of interest.

\section{References}

1. Abou-Elela, S.I.;Nasr, F.A.; El-Shafai, S.A. Wastewater management in small- and medium-size enterprises: Case studies. Environmentalist 2008, 28, 289-296.

2. Ozgun, H.; Karagul, N.; Dereli, R.K.; Ersahin, M.E.; Coskuner, T.; Ciftci, D.I.; Ozturk, I.; Altinbas, M. Confectionery industry: A case study on treatability-based effluent characterization and treatment system performance. Water Sci. Technol. 2012, 66, 15-20.

3. Sahu, O.P.; Chaudhari, P.K.; Electrochemical treatment of sugar industry wastewater: COD and color removal. J. Electroanal. Chem. 2015, 739, 122-129.

4. Krzanowski, S.; Wałega, A.; Paśmionka, I. Oczyszczanie ścieków z wybranych zakładów przemysłu spożywczego; Infrastruktura i ekologia terenów wiejskich: Kraków, Poland, 2008.

5. Bunani, S.; Yörükoğlu, E.; Sert, G.; Yüksel, Ü.; Yüksel, M.; Kabay, N. Application of nanofiltration for reuse of municipal wastewater and quality analysis of product water. Desalination 2013, 315, 33-36.

6. Egea-Corbacho, A.; Gutiérrez, S.; Quiroga, J.M. Removal of emerging contaminants from wastewater using nanofiltration for its subsequent reuse: Fullescale pilot plant. J. Clean. Prod. 2019, 214, 514-523.

7. Ranganathan, K.; Karunagaran, K.; Sharma, D.C. Recycling of wastewaters of textile dyeing industries using advanced treatment technology and cost analysis-Case studies. Resour. Conserv. Recy. 2007, 50, 306318.

(C) 2019 by the authors. Licensee MDPI, Basel, Switzerland. This article is an open access article distributed under the terms and conditions of the Creative Commons Attribution (CC BY) license (http://creativecommons.org/licenses/by/4.0/). 